\title{
Angiotensin II upregulates the expression of placental growth factor in human vascular endothelial cells and smooth muscle cells
}

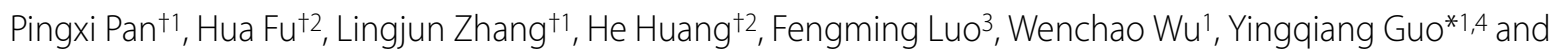
Xiaojing Liu*1

\begin{abstract}
Background: Atherosclerosis is now recognized as a chronic inflammatory disease. Angiotensin II (Ang II) is a critical factor in inflammatory responses, which promotes the pathogenesis of atherosclerosis. Placental growth factor (PIGF) is a member of the vascular endothelial growth factor (VEGF) family cytokines and is associated with inflammatory progress of atherosclerosis. However, the potential link between PIGF and Ang II has not been investigated. In the current study, whether Ang II could regulate PIGF expression, and the effect of PIGF on cell proliferation, was investigated in human vascular endothelial cells (VECs) and smooth muscle cells (VSMCs).

Results: In growth-arrested human VECs and VSMCs, Ang II induced PIGF mRNA expression after 4 hour treatment, and peaked at 24 hours. $10^{-6} \mathrm{~mol} / \mathrm{L}$ Ang II increased PIGF protein production after 8 hour treatment, and peaked at 24 hours. Stimulation with Ang II also induced mRNA expression of VEGF receptor-1 and -2(VEGFR-1 and -2) in these cells. The Ang II type I receptor $\left(\mathrm{AT}_{1} \mathrm{R}\right)$ antagonist blocked Ang II-induced PIGF gene expression and protein production. Several intracellular signals elicited by Ang II were involved in PIGF synthesis, including activation of protein kinase C, extracellular signal-regulated kinase 1/2 (ERK1/2) and PI3-kinase. A neutralizing antibody against PIGF partially inhibited the Ang II-induced proliferation of VECs and VSMCs. However, this antibody showed little effect on the basal proliferation in these cells, whereas blocking antibody of VEGF could suppress both basal and Ang II-induced proliferation in VECs and VSMCs.

Conclusion: Our results showed for the first time that Ang II could induce the gene expression and protein production of PIGF in VECs and VSMCs, which might play an important role in the pathogenesis of vascular inflammation and atherosclerosis.
\end{abstract}

\section{Background}

Atherosclerosis is now considered to be a chronic inflammatory process which may ultimately lead to acute myocardial infarction, cerebrovascular and peripheral vascular diseases [1,2]. Plenty of data suggest that the rennin-angiotensin system (RAS) plays an important role in

*Correspondence: drguoyq@hotmail.com, xiaojingliu67@yahoo.com¹

Laboratory of Cardiovascular Diseases, National key Laboratory of Biotherapy of Human Diseases, West China Hospital, Sichuan University, Chengdu 610041, China

1 Laboratory of Cardiovascular Diseases, National key Laboratory of Biotherapy of Human Diseases, West China Hospital, Sichuan University, Chengdu 610041, China

+ Contributed equally

Full list of author information is available at the end of the article the development of many cardiovascular diseases, including the pathophysiological process of atherosclerosis $[3,4]$. Many studies have shown that inhibition of the RAS could reduce inflammation and oxidative stress [5]. Angiotensin II (Ang II), one of the major effectors of the RAS, is a cytokine that regulates cell growth, inflammation and fibrosis contributing to the progression of vascular damage $[4,6,7]$. Ang II participates in atherosclerosis pathogenesis by inducing inflammation and apoptosis, facilitating absorption of oxidative low density lipoprotein, generating oxygenic radicals and impacting fibrinolysis function [7]. The physiological actions of Ang II are mediated via its type 1 receptor $\left(\mathrm{AT}_{1} \mathrm{R}\right)$ and type 2 receptor $\left(\mathrm{AT}_{2} \mathrm{R}\right)$, which are expressed under different develop- 
mental, tissue-specific, and disease-specific conditions $[8,9]$. It has been shown that Ang II activates NF- $\mathrm{kB}$, a key component of inflammation, in vascular smooth muscle cells (VSMCs)[10]. However, the exact mechanism of Ang II-mediated inflammation in vascular endothelial cells (VECs) or VSMCs is still largely unclear.

Recently, Placenta growth factor (PlGF) has emerged as a key factor in vascular inflammation and progression of atherosclerosis [11-13]. PlGF is a member of the vascular endothelial growth factor (VEGF) family cytokines and is associated with inflammation and with pathologic angiogenesis [14-16]. It is a polypeptide growth hormone that binds to Flt-1-receptor (VEGFR-1), neuropilin-1 (NRP1) and neuropilin-2 (NRP2) receptors, but not to VEGFreceptor type 2 (VEGFR-2)[14]. Recent study has shown that PIGF is required for macrophage infiltration in early atherosclerotic lesions in apolipoprotein E-deficient mice [11]. PlGF has atherogenic properties including recruitment and adhesion of monocytes, induction the production of proteinase, and thrombus formation through stimulating tissue factor secretion [12]. It is up-regulated in early and advanced atherosclerotic lesions, acting as a primary inflammatory instigator of atherosclerotic plaque instability[12]. Moreover, it has been recognized as an independent biomarker of adverse outcome in patients with acute coronary syndromes (ACS) [13,17]. As a more specific marker of vascular inflammation, PlGF might be considered for risk stratification of patients with ACS[13]. The PIGF expression can be induced by hypoxia and various pro-inflammatory stimuli [18]. This induction is mediated via NF-kappa B and metal response transcription factor-1(MTF-1)[19]. However, the regulation of PlGF expression in vascular cells, and its mechanisms of action have received little attention in atherosclerosis research.

Because PlGF plays a role in initiation and progression of atherosclerosis, it is interesting to examine the potential interaction between Ang II and PlGF. However, the connection between Ang II and PlGF expression in vascular cells has not been studied. In this study, we examined the effect of Ang II on the PIGF expression in both human VECs and VSMCs. Previously, the HUVECderived endothelial cell line (EA.Hy 926) [20,21] and human umbilical artery smooth muscle cells (HUASMCs) [22,23] have been characterized as models of investigating the functions of VECs and VSMC, respectively. EA.Hy 926 endothelial cells and HUASMCs were used in the present study.

\section{Results}

Angiotensin II increases PIGF mRNA and protein levels in both EA.Hy 926 cells and HUASMCs

The human umbilical vein endothelial cell-derived cell line EA.Hy 926 was used in this study. As an established cell line, EA.Hy 926 cell is homogenous compare to the variable primary cells from individual donors.

To determine whether Ang II modulates PlGF gene expression in VECs, EA.Hy 926 endothelial cells were treated with different concentrations of Ang II. Total RNA was isolated at various time points (up to 48 hours). After 4 hour treatment, real-time quantitative RT-PCR revealed that $10^{-6} \mathrm{~mol} / \mathrm{L}$ concentration of Ang II induced the expression of PlGF above basal levels, and the induction was peaked at 24 hours after treatment (Figure 1A). The induction of PlGF mRNA by Ang II was best at $10^{-6}$ $\mathrm{mol} / \mathrm{L}$ and was less effective at $10^{-7} \mathrm{~mol} / \mathrm{L}$ or $10^{-5} \mathrm{~mol} / \mathrm{L}$ (Figure 1B). Standard concentration of $10^{-6} \mathrm{~mol} / \mathrm{L}$ Ang II was used for all further experiments. Similarly, Ang II at $10^{-6} \mathrm{~mol} / \mathrm{L}$ also led to a time-dependent increase of PlGF mRNA expression in HUASMCs (Figure 1A).

Next, we examined the Ang II- induced change of PlGF protein level in EA.Hy 926 endothelial cells and HUASMCs. Cells were exposed to Ang II treatment for indicated times. Subsequently, the secretion of PlGF in the culture media was measured by ELISA. Under serumstarvation condition, EA.Hy 926 cells secreted low level of PlGF ( $12 \mathrm{pg} / \mathrm{mL})$. Treatment with Ang II for 8, 24 or 48 hours evoked significant secretion of PlGF, as compared to the untreated cells (Figure 1C). Similarly, the growth-arrested HUASMCs released low level of PIGF protein in the cell culture supernatant. When HUASMCs were treated with Ang II for 24 or $48 \mathrm{hrs,} \mathrm{the} \mathrm{PlGF} \mathrm{pro-}$ duction was significantly higher than that in untreated cells (Figure 1C).

The expression of PlGF was also analyzed by immunofluorence technique. Only weak PlGF fluorescence intensity was observed in growth-arrested EA.Hy 926 cells and HUASMCs. Ang II stimulation for 24 hours significantly increased the cytoplasmic PlGF fluorescence intensity in both cell types (Figure 1D).

Taken together, our data indicated that Ang II increased PIGF mRNA and protein production in EA.Hy 926 cells and HUASMCs.

\section{Angiotensin Il increases VEGFR-1 and VEGFR-2 mRNA expression in both EA.Hy 926 cells and HUASMCs}

VEGF is a the major initiator of angiogenesis and its actions are mediated via two major receptors, VEGFR1(Flt-1) and VEGFR-2(KDR) [24,25]. VEGF is an essential mediator in Ang II-induced vascular inflammation and structural changes through its proinflammatory actions [24]. In order to investigate the possible role of VEGF and its receptors in our experimental model, we first measured the release of VEGF in the culture supernatant of these cells. Our results showed that treatment with Ang II significantly increased the release of VEGF in the cell culture supernatant (Figure 2A). We also examined the VEGFR-1 and VEGFR-2 gene expression by real-time 

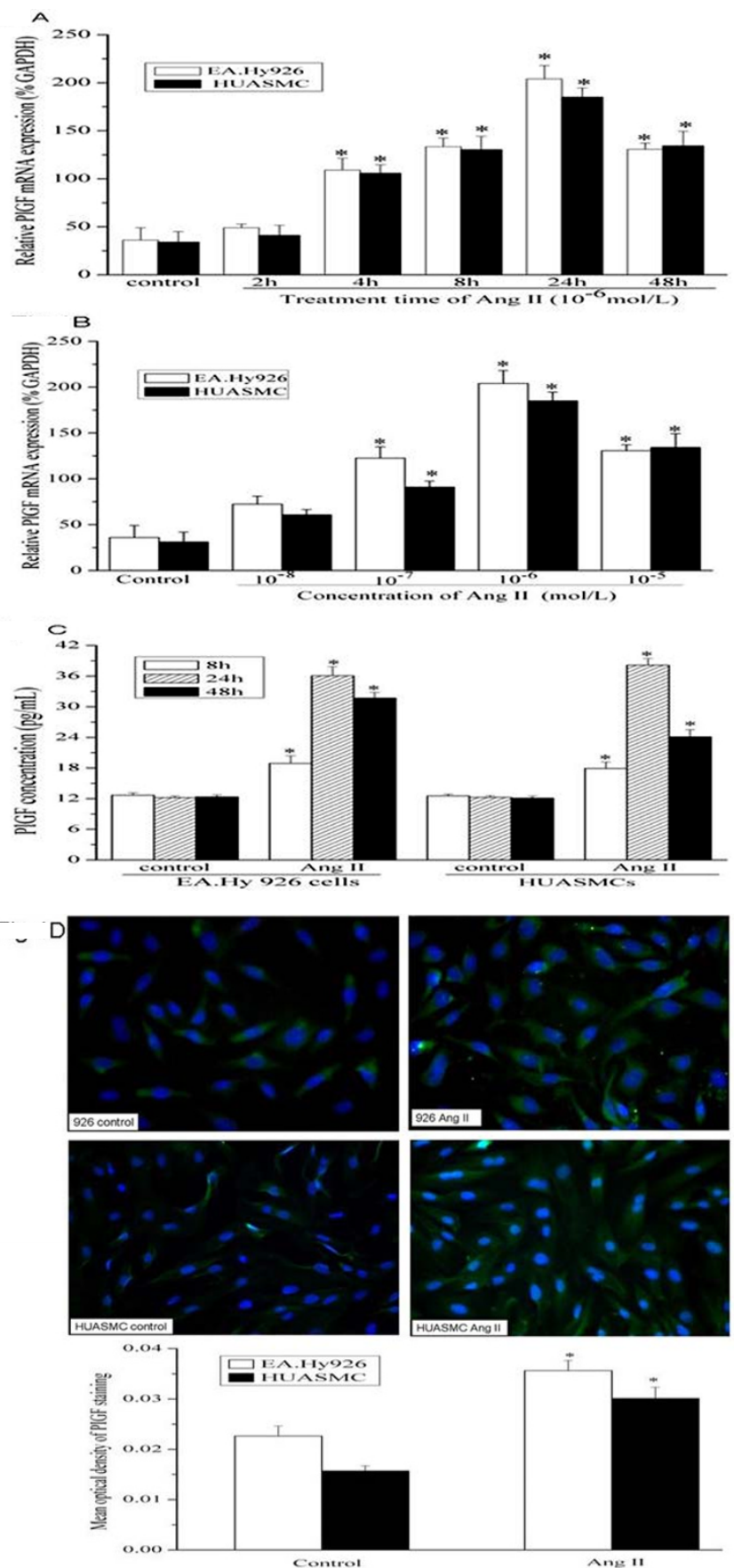

Figure 1 Angiotensin II increases PIGF mRNA expression (A, B) and protein production (C, D) in EA.Hy 926 endothelial cells and HUASMCs. Growth-arrested EA.Hy 926 cells and HUASMCs were stimulated with Angiotensin II (10-6 mol/L) for different durations. (A) Quantitative RT-PCR (QPCR) results. Total RNA was isolated from cells. After reverse transcription, they were subjected to quantitative PCR analysis to determine PIGF mRNA level. Graph is representative of relative PIGF mRNA levels in the various conditions. Experiments were performed five times with the similar results (n $=5$ in each group). ${ }^{*}$ indicates $P<0.05$ vs control EA.Hy 926 cells or HUASMCs. (B) Induction of PIGF mRNA expression is Ang II concentration-dependent. * indicates $P<0.05$ vs control EA.Hy 926 cells or HUASMCs. (C) Release of PIGF protein measured by ELISA. Cells were incubated with Ang II (10${ }^{6} \mathrm{~mol} / \mathrm{L}$ ) for 8,24 or $48 \mathrm{~h}$, and PIGF protein released into cell culture media was measured by ELISA ( $\mathrm{n}=3$ in each group). ${ }^{*}$ indicates $P<0.05 \mathrm{vs}$ control EA.Hy 926 cells or HUASMCs. (D) Expression of PIGF protein detected by immunofluorescence assay. Immunofluorescence detecting of PIGF expression in untreated control cells, and cells stimulated with Ang II $\left(10^{-6} \mathrm{~mol} / \mathrm{L}\right)$ for 24 hours (original magnification of $\left.200 \times\right)$. Mean optical density (MOD) of PIGF staining was measured on the images by using the ImageJ software. The figure shows one of three similar experiments. ${ }^{*} P<0.05 \mathrm{vs}$ control EA.Hy 926 cells or HUASMCs. 


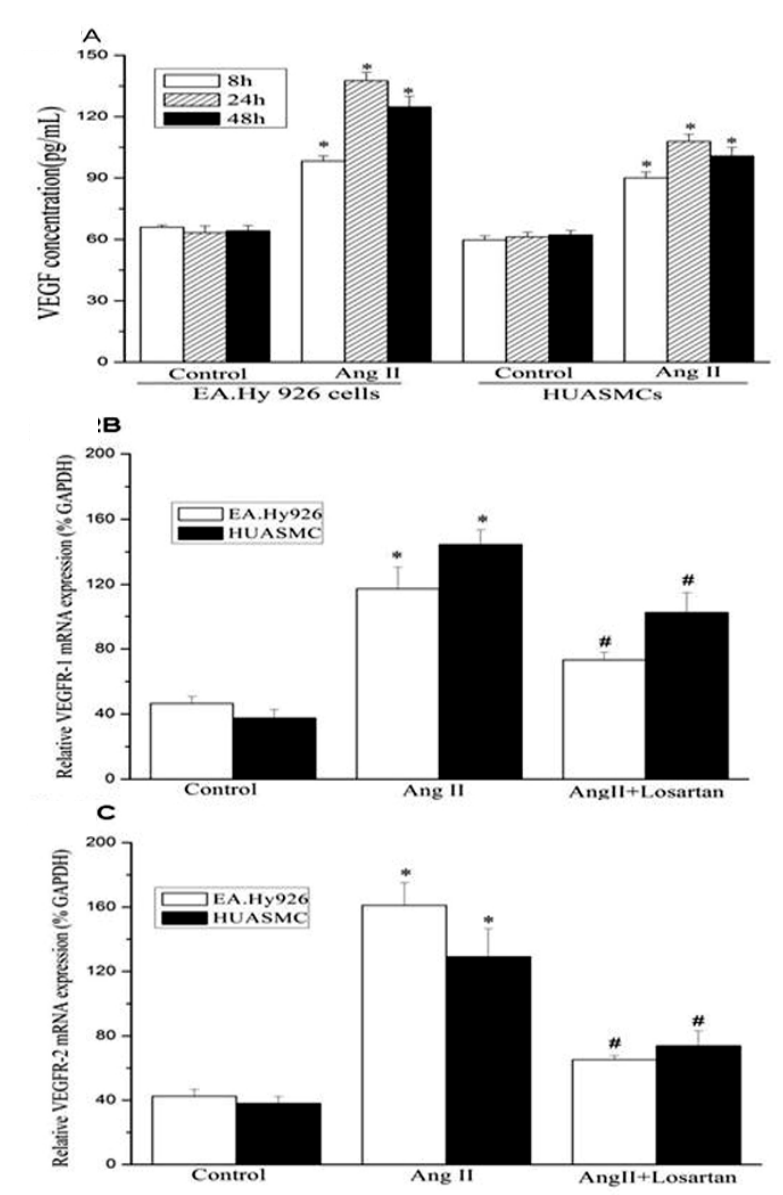

Figure 2 Angiotensin II increases VEGF release (A) and VEGFR-1 and -2 mRNA expressions $(B, C)$ in EA.Hy 926 endothelial cells and HUASMCs. (A) Release of VEGF in the cell culture media measured by ELISA. Growth-arrested cells were incubated with Ang II (10-7, $10^{-6}$ and $10^{-5} \mathrm{~mol} / \mathrm{L}$ ) for $8 \mathrm{hrs}, 24 \mathrm{hrsor} 48 \mathrm{hrs}$, and VEGF protein released into cell culture media was measured by ELISA ( $n=3$ in each group). * indicates $P<0.05$ vs control EA.Hy 926 cells or HUASMCs. (B) Real-time PCR results: Ang II induced VEGFR-1 mRNA expression in both EA.Hy 926 endothelial cells and HUASMCs. * indicates $P<0.05$ vs control EA.Hy 926 cells or HUASMCs. \# indicates $P<0.05$ vs cells treated with Ang II. (C) Real-time PCR results: Ang II induced VEGFR-2 mRNA expression in both EA.Hy 926 endothelial cells and HUASMCs. * indicates $P<0.05$ vs control EA.Hy 926 cells or HUASMCs. \# indicates $P<0.05$ vs cells treated with Ang II.

PCR. We showed that the expression of both VEGFR-1 and -2 mRNA were induced upon Ang II stimulation. This induction of VEGFR gene expression was abolished by the $\mathrm{AT}_{1} \mathrm{R}$ blocker, Losartan (Figure $2 \mathrm{~B}$ and $2 \mathrm{C}$ ). Our results confirmed that VEGF and its receptors might be involved in Ang II actions in VECs and VSMCs.

\section{Angiotensin II increases PIGF expression via $\mathrm{AT}_{1} \mathrm{R}$ in both EA.Hy 926 cells and HUASMCs}

In VECs and VSMCs, Ang II acts through two specific receptors, $A_{1} R$ and $A T_{2} R$ [8]. To evaluate the roles of the two receptors in the Ang II-induced PlGF expression, EA.Hy926 cells and HUASMCs were pre-treated with the two receptor antagonists, and then incubated with Ang II. The $\mathrm{AT}_{1} \mathrm{R}$ antagonist Losartan caused a significant decrease in Ang II-induced PlGF expression at both mRNA and protein levels (Figure 3), whereas the $\mathrm{AT}_{2} \mathrm{R}$ antagonist PD 123319 had no effect, suggested that Ang II-inuced PIGF up-regulation was mediated through its $\mathrm{AT}_{1}$ receptor.

\section{Signaling mechanisms involved in Angiotensin II-induced PIGF gene and protein production}

Ang II, via $\mathrm{AT}_{1} \mathrm{R}$, activates several intracellular signaling pathways, including PKC, ERK1/2 and PI-3K [26-28]. To evaluate the roles of downstream signaling in the Ang IIinduced PlGF expression, EA.Hy926 cells and HUASMCs were pre-treated with kinase inhibitors Calphostin $C$,

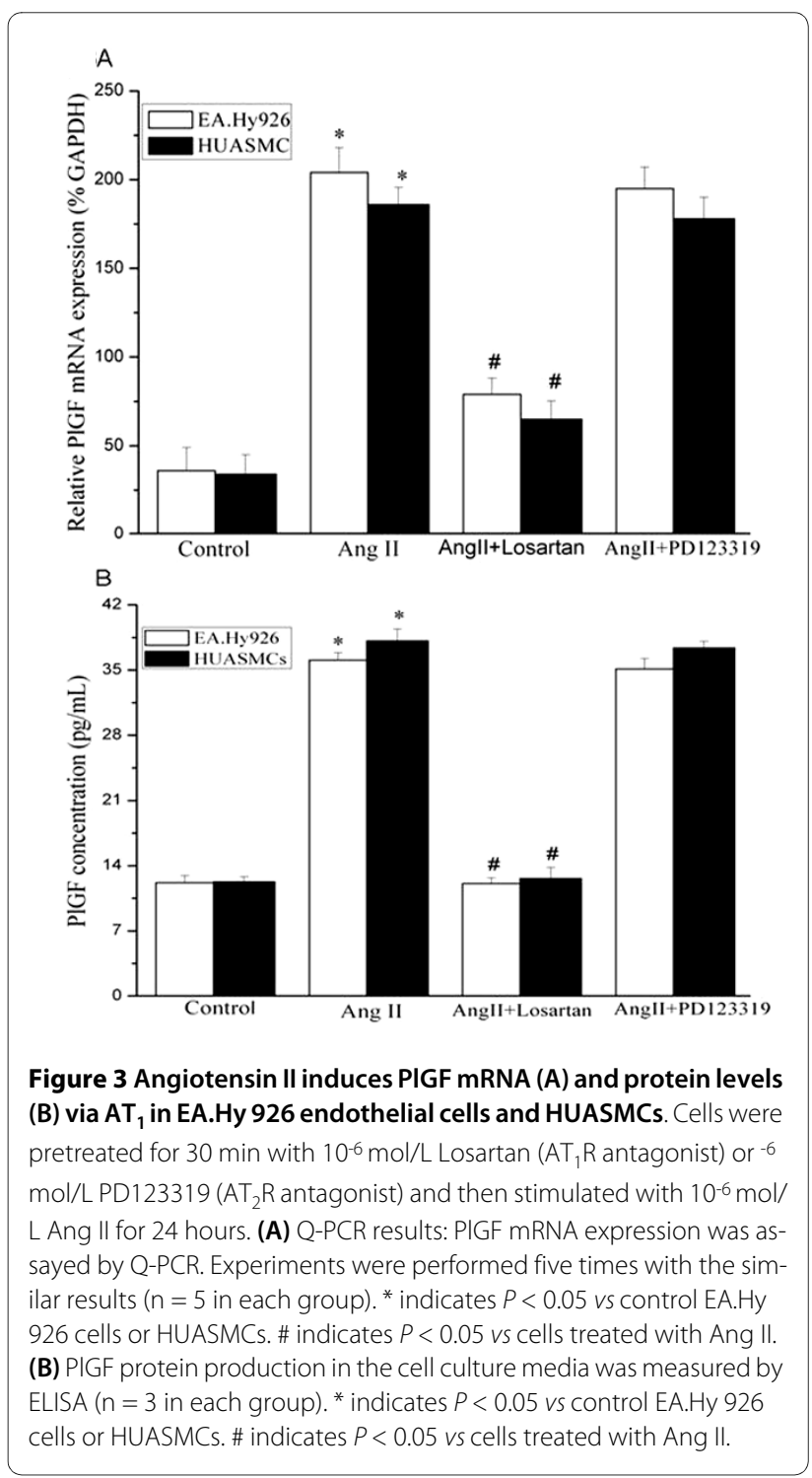


PD98059 or Wortmannin. By using quantitative RT-PCR and ELISA, subsequent signal inhibition experiments revealed that treatment with Calphostin C, PD98059, and Wortmannin significantly decreased the Ang II-induced PlGF mRNA and protein expression in the both cell types (Figure 4). These data suggest that, PKC, ERK1/2 and PI$3 \mathrm{~K}$ all involved in stimulating PlGF expression by Ang II.

\section{Role of PIGF in the Angiotensin II-induced proliferation of} EA.Hy 926 cells and HUASMCs

In order to examine if PlGF or VEGF played a role in Ang II-induced proliferation, we used MTT incorporation assay $[29,30]$ to study the proliferation of growth-arrested EA.Hy 926 cells and HUASMCs followed by (1) Ang II treatment, or (2) co-treatment of Ang II and a neutralizing antibody against to PlGF or VEGF (10 or $20 \mu \mathrm{g} / \mathrm{mL})$, or (3) administration of the blocking antibody for PlGF or VEGF alone for $24 \mathrm{~h}$.

Figure 5 shows that, similar to other reports[31,32] in which administration of Ang II stimulated the proliferation of cultured vascular cells, treatment with Ang II (10-6 $\mathrm{mol} / \mathrm{L}$ ) for 24 hours significantly increased EA.Hy 926 cell proliferation by $138 \%$ compared to the control; and increased HUASMCs proliferation by $91.6 \%$. A neutralizing antibody specific to PlGF inhibited Ang II-induced proliferation in EA.Hy 926 cells (40.9\% inhibition), and to a less extent, in HUASMCs (26.8\% inhibition) (Fig. 5A). Moreover, a neutralizing antibody specific to VEGF inhibited Ang II-induced proliferation in EA.Hy 926 cells (43.3\% inhibition), and to a less extent, in HUASMCs (35.5\% inhibition) (Fig 5B). Ang II-stimulated cell proliferation was suppressed by the simultaneous administra-
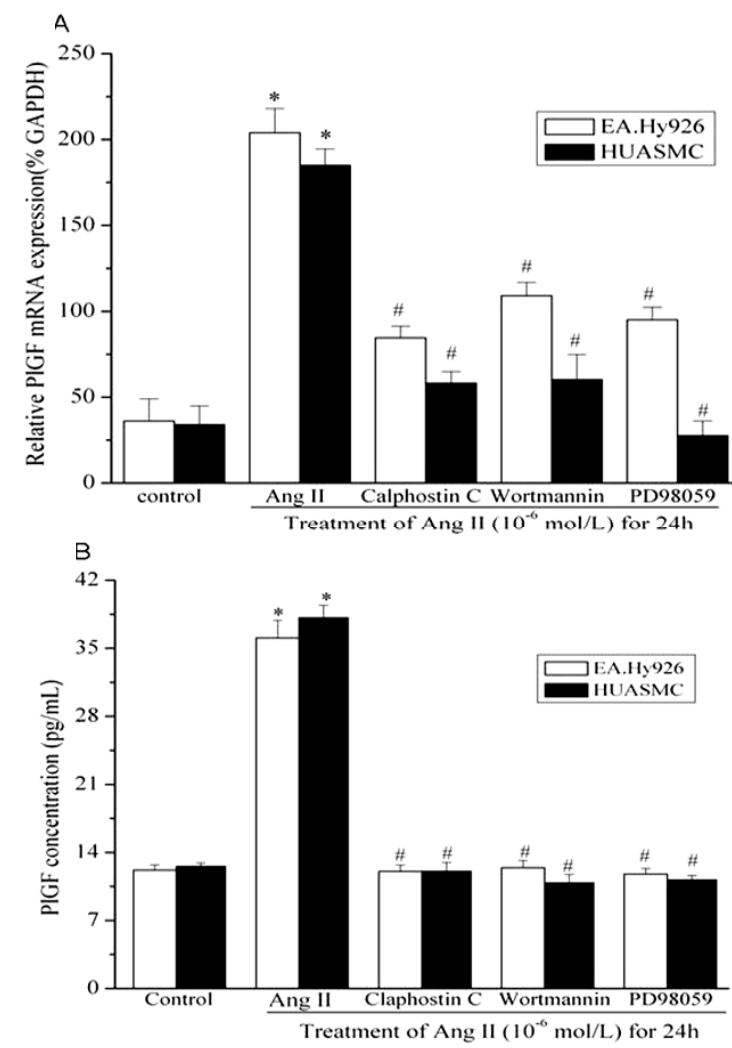

Figure 4 Molecular mechanisms involved in Angiotensin II-induced PIGF upregulation in EA.Hy 926 cells and HUASMCs. (A) Effects of different inhibitors on the PIGF mRNA expression induced by Ang II by using Quantitative RT-PCR. Cells were pretreated with different inhibitors for 30 mins and stimulated with Ang $\|\left(10^{-6} \mathrm{~mol} / \mathrm{L}\right)$ for 24 hours, and PIGF mRNA expression was assayed by Q-PCR ( $\mathrm{n}=3$ in each group). ${ }^{*} P<0.05$ vs control cells. \# $P<0.05$ vs cells treated with Ang II alone. (B) Effects of different inhibitors on the PIGF protein expression induced by Ang II detected by using ELISA. PIGF protein contents in the cell culture media were assayed by ELISA ( $n=3$ in each group). * $P$ $<0.05$ vs control cells. \# $P<0.05$ vs cells treated with Ang II alone.
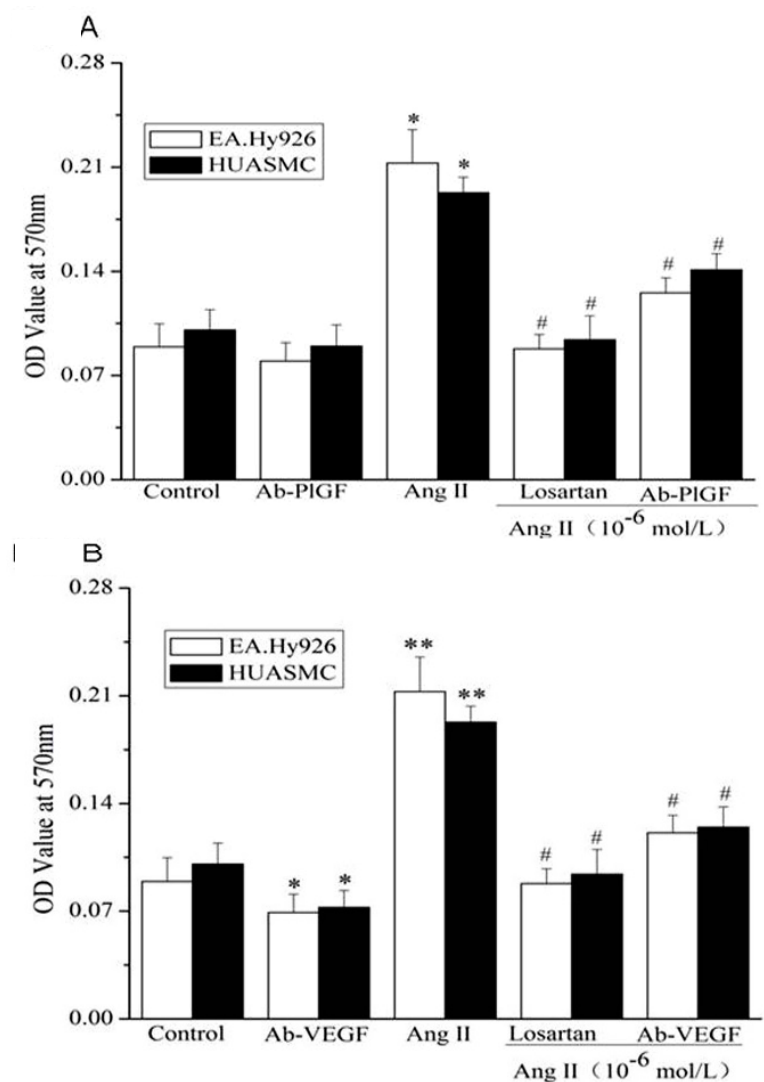

Figure 5 PIGF and VEGF is involved in Angiotensin II-induced proliferation of cultured EA.Hy 926 cells and HUASMCs. Quiescent cells were treated with Ang $\|\left(10^{-6} \mathrm{~mol} / \mathrm{L}\right)$, Ang $\|\left(10^{-6} \mathrm{~mol} / \mathrm{L}\right)$ and Losar$\tan \left(10^{-6} \mathrm{~mol} / \mathrm{L}\right)$, Ang $\|\left(10^{-6} \mathrm{~mol} / \mathrm{L}\right)$ and the specific neutralizing antibody to PIGF(A) or VEGF (B) $(20 \mu \mathrm{g} / \mathrm{mL})$ for 24 hours, followed by the assessment of cell proliferation by MTT assay. Each value is the mean \pm SD of 5 separate determinations. ${ }^{*}$ indicates $P<0.05$ vs control cells. \# indicates $P<0.05$ vs cells treated with Ang II. Ab-PIGF: the specific neutralizing antibody against PIGF. Ab-VEGF: the blocking antibody to VEGF. 
tion of the $\mathrm{AT}_{1} \mathrm{R}$ blocker Losartan $(69.8 \%$ and $62.2 \%$ inhibition rate in EA.Hy 926 and HUASMCs respectively). However, administration of blocking antibody to PIGF alone had no effect on the proliferation in these vascular cells, while the blocking antibody to VEGF alone could significantly suppressed the proliferation rate in both EA.Hy 926 cells and in HUASMCs. Our data indicated that PIGF was involved in Ang II-induced proliferation of EA.Hy 926 cells and HUASMCs, whereas VEGF was implicated in both basal and Ang II-induced proliferation in these cells.

\section{Discussion and Conclusions}

In the present study, the potential correlation between Ang II and PlGF was investigated in cultured EA.Hy 926 endothelial cells and in HUASMCs. The major findings of this study are: (1) Ang II, via $\mathrm{AT}_{1} \mathrm{R}$, induces PlGF gene expression and protein secretion in both VECs and VSMCs; (2) Ang II increases VEGFR-1 and -2 gene expression in these vascular cells; (3) multiple signaling pathways, including PKC, ERK1/2 and PI3-K, are involved in this Ang II-induced PIGF upregulation; (4) blockade of PIGF results in the inhibition of Ang IIinduced proliferation in these cells, whereas blockade of VEGF leads to inhibition of both basal and Ang II-elicited proliferation. Our observations established a role of PlGF in mediating Ang II-induced proliferation in vascular endothelial cells and vascular smooth muscle cells. In addition, our results suggested that inhibition of PlGF or VEGF might be useful in preventing abnormal VEC or VSMC proliferation evoked by Ang II.

Numerous studies suggest that the renin-angiotensin system (RAS) contributes to the pathogenesis of atherosclerosis [4,7]. Angiotensin II, the principal effecter of the RAS, is not only a vasoactive hormone, but also a cytokine that regulates cell proliferation, inflammation and fibrosis. Ang II elicits the inflammatory response by stimulating the production of chemokines, cytokines, and adhesion molecules [10]. Recent study demonstrated that Ang II induced vascular endothelial cell proliferation by increasing the expression of the angiogenic factor VEGF [31]. Consistent with previous reports [24,25,31], we observed that Ang II increased VEGF and its two receptors expression in our experimental model. Meanwhile, our data provided direct evidence that, in vascular endothelial cell and smooth muscle cells, Ang II, via its $\mathrm{AT}_{1}$ receptor, could up-regulate PIGF expression. These results suggested that Ang II might participate in the regulation of pathological angiogenesis.

Ang II acts through binding to its specific $\mathrm{AT}_{1}$ and $\mathrm{AT}_{2}$ receptors, which are seven transmembrane glycoproteins with $30 \%$ sequence similarity [8]. The $\mathrm{AT}_{1} \mathrm{R}$ is a classical $\mathrm{G}$ protein-coupled receptor, whereas $\mathrm{AT}_{2} \mathrm{R}$ often antago- nizes the effects of signaling through the $\mathrm{AT}_{1} \mathrm{R}[9]$. Many $\mathrm{AT}_{1} \mathrm{R}$-induced growth responses are mediated by transactivation of growth factor receptors. $\mathrm{AT}_{1}$ receptor regulates cell proliferation, cytokines production and some pathological processes, including Ang II-induced hypertension and cardiac hypertrophy. Although $\mathrm{AT}_{1}$ receptor mediates most of the recognized cardiovascular effects of Ang II, the $\mathrm{AT}_{2}$ receptor contributes to the regulation of blood pressure and renal function. Our data demonstrated that, in cultured EA.Hy 926 endothelial cells and HUASMCs, Ang II increased PlGF expression and synthesis via its $\mathrm{AT}_{1}$ receptor.

Several pathways, e.g. PKC [26], ERK1/2 [7,26,33], and PI3K/Akt [34], involved in $\mathrm{AT}_{1} \mathrm{R}$ activation. Using specific inhibitors, the present study showed that Ang II activated PKC, ERK1/2 and PI-3K pathways. The activation of all these pathways contributed to PlGF up-regulation in EA.Hy 926 endothelial cells and HUASMCs.

The induction of PlGF gene expression by Ang II may be of considerable clinical significance, especially in vascular inflammation and atherosclerosis. Pro-inflammatory cytokines play a crucial role of in the development of atherosclerosis and plaque instability. Quiescent vascular endothelial cells only release minimal amounts of PlGF. In contrast, activated endothelial cells could produce large amounts of PlGF[35]. Previous studies demonstrated that PlGF activated monocytes and increased the expression of tumor necrosis factor- $\alpha$ (TNF- $\alpha)$, interleukin-1 $\beta$ (IL-1 $\beta$ ), and monocyte chemotactic protein1 (MCP-1) in monocytes[36,37]. Consequently, when stimulated by Ang II, vascular endothelial cells produce PlGF, which activates neutrophils and monocytes, results in their adherence to endothelial cells. This might trigger the pathophysiological changes observed in atherosclerosis. Our results indicated that, the administration of PIGF-neutralizing antibody significantly inhibited the Ang II-dependent proliferation of vascular endothelial cells, suggested that PIGF might be a down-stream angiogenic mediator of RAS. The neutralizing antibodies of PIGF or VEGF are less effective in inhibiting cell proliferation than the small molecule inhibitor of $\mathrm{AT}_{1} \mathrm{R}$, since other effects are involved besides VEGF/PIGF production. It has been largely demonstrated that the Ang IIinduced VSMC proliferation is mediated by PDGF and Egr-1 $[38,39]$. And the $\mathrm{AT}_{1} \mathrm{R}$ blocker might be useful as an anti-angiogenic agent.

It has been recognized that VSMC proliferation within the vessel wall is an important pathogenic feature in the development of atherosclerosis [40,41]. Ang II has been implicated to play an important role in this cellular mechanism. When exposed to hypoxia $\left(3 \% \mathrm{O}_{2}\right)$, the proliferation and contraction of VSMC were enhanced by PIGF treatment [42]. Furthermore, recent study has shown that 
PIGF expression in human atherosclerotic carotid plaques is related to inflammation and clinical plaque instability[12]. Present observations showed that Ang II induced PlGF expression in VSMC, suggested a role of PlGF in mediating VSMC proliferation induced by Ang II.

It has been shown that Ang II could stimulate the expression of hypoxia inducible factor- $1 \alpha$ (HIF- $1 \alpha)$ [43], and HIF-1 $\alpha$ seems to be involved in the enhanced PlGF expression stimulated by hypoxia [19]. The hypoxiainducible PlGF expression is mediated through NF-kB, metal-regulatory transcription factor-1(MTF-1) and the interaction between them [19]. Ang II-induced PlGF expression might be mediated through the HIF-1 $\alpha$ pathways. However, future studies in vascular cells are necessary to determine the role of Ang II receptors and PIGF in atherosclerosis.

In conclusion, PlGF might be one of the downstream effectors up-regulated by Ang II in vascular diseases. Several pathways, such as PKC and ERK 1/2 activation, seem to be involved in the Ang II-induced PlGF expression in vascular cells. PIGF also mediates Ang II-induced cell proliferation in VECs and HUASMCs. Thus, our study provides new insights into PlGF as one of the Ang IIinducible genes. The link of PlGF to Ang II might be a novel molecular mechanism to target cardiovascular diseases.

\section{Methods}

\section{Cell Culture}

A human endothelial cell line (EA.Hy 926) was grown in RPMI 1640 (GIBCO-BRL) supplemented with 10\% FBS, $1 \%$ penicillin/streptomycin, $2 \mathrm{mmol} / \mathrm{L} \mathrm{L}$-glutamine and 1\% HAT (Sigma, USA).

Primary cultures of HUASMCs were isolated from freshly delivered umbilical cords by tissue explanting method [22,23] and maintained in DMEM medium (GIBCO-BRL) supplemented with $20 \%$ fetal bovine serum (FBS) (Hyclone), $2 \mathrm{mmol} / \mathrm{L}$ L-glutamine, and 1\% penicillin-streptomycin. All cell cultures were maintained in a humidified $5 \% \mathrm{CO}_{2} / 95 \%$ air incubator at $37^{\circ} \mathrm{C}$. HUASMCs were identified by the specific marker of vascular smooth muscle cell $(\alpha$-smooth muscle actin, $\alpha$ SMA) immunofluorescence. The study was approved by the medical ethics committee of the West China Hospital, Sichuan University.

In all experiments, confluent EA.Hy 926 cells or HUASMC cells at passage 4 to 8 were washed and incubated with serum-free media for 24 hours. These cells were treated with human angiotensin II (Ang II, $10^{-6} \mathrm{~mol} /$ L) for different time points. In some experiments, cells were pre-treated for 30 minutes with $10^{-7} \mathrm{~mol} / \mathrm{L}$ Wortmannin, $10^{-6} \mathrm{~mol} / \mathrm{L}$ Calphostin C, $10^{-6} \mathrm{~mol} / \mathrm{L}$ PD98059, $10^{-6} \mathrm{~mol} / \mathrm{L}$ Losartan $\left(\mathrm{AT}_{1} \mathrm{R}\right.$ antagonist) or $10^{-6} \mathrm{~mol} / \mathrm{L}$
PD123319( $\mathrm{AT}_{2} \mathrm{R}$ antagonist), and then stimulated with $10^{-6} \mathrm{~mol} / \mathrm{L}$ Ang II for different time points.

\section{Quantitative reverse transcription PCR (Real-time RT-PCR)}

The expression of PlGF gene was identified by quantitative RT-PCR (Q-PCR) as reported earlier [44]. Total RNA was extracted from HUASMCs or EA.Hy 926 cells using TRIZOL reagent (Invitrogen, USA). Q-PCR was carried out on an ABI Prism 7300 PCR Detection System (Applied Biosystems, USA) with fluorescence dye SYBR Green (SYBR Green Real-time PCR Master Mix, TOYOBO, Japan). The sequences of the primers were as follows: PlGF-F: 5'-GTT CAG CCC ATC CTG TGT CT3'; PlGF-R: 5'-CTT CAT CTT CTC CCG CAG AG-3'. GAPDH-F: 5'-ACC ACA GT CCA TGC CAT CAC-3'; GAPDH-R: 5'-TCC ACC ACC CTG TTG CTG TA-3'. VEGFR-1-F: 5'-ATC ATT CCG AAG CAA GGT GTG-3'; VEGFR-1-R: 5'-AAA CCC ATT TGG CAC ATC TGT-3'. VEGFR-2-F: 5'-CAC CAC TCA AAC GCT GAC ATG TA-3'; VEGFR-2-R: 5'-GCT CGT TGG CGC ACT CTT3 '. The thermal cycling conditions were as following: $95^{\circ} \mathrm{C}$ 60 seconds, 40 cycles of $95^{\circ} \mathrm{C}$ for 15 seconds, $56^{\circ} \mathrm{C}$ for 15 seconds, $72^{\circ} \mathrm{C}$ for 45 seconds (data collection). Data analysis was carried out by ABI sequence detection software using relative quantification. For quantification, the target sequence was normalized to the GAPDH mRNA levels.

\section{Quantification of PIGF and VEGF by ELISA}

The PIGF or VEGF levels in the cell culture supernatant were measured by a "sandwich" enzyme immunoassay (Quantikine ELISA, R\&D Systems, USA) according to manufacture's instructions. Briefly, the samples were added to 96-well plates coated with a specific monoclonal antibody to PIGF or VEGF. The unbound protein was washed three times, and an enzyme-linked polyclonal antibody specific to PlGF or VEGF was added. The plates were washed again for three times, and substrate solution was added to the wells. After 30 min of incubation, stop solution was added to each well. The amount of PlGF or VEGF was determined by optical density of the samples by comparison with the standards at $450 \mathrm{~nm}$ using an ELISA reader (Bio-Rad Model 680, USA).

\section{Detection PIGF protein expression by immunofluorescence} EA.Hy 926 cells or HUASMCs were plated onto coverslips in 6-well plates, growth arrested and treated with Ang II at $10^{-6} \mathrm{~mol} / \mathrm{L}$ concentration with or without other compounds. After that, the cells on the glass slides were then fixed and blocked as described before [31], followed by exposed to the primary anti-PlGF antibody. The second antibody was FITC-conjugated antibody and the cell nuclei were stained with DAPI (Sigma-Aldrich). Images were collected using an Eclipse TE2000-U fluorescent 
microscope system (Nikon, Japan) and analyzed with ImageJ software from NIH Image to semi-quantitatively determine the expression of PIGF protein in the cytoplasm of the cells.

\section{Assessment of cell proliferation}

The effect of Ang II and antagonists to PlGF or VEGF on cell proliferation was determined by the 3-(4,5-dimethylthiazol-2-yl)-2,5-diphenyltetrazolium bromide (MTT) assay, as described previously[29]. Briefly, EA.Hy 926 cells or HUASMC cells were subcultured in 96-well plates and incubated with serum-free medium for 24 hours. Quiescent cultures were treated with the Ang II $\left(10^{-6}\right.$ $\mathrm{mol} / \mathrm{L})$, Ang II $\left(10^{-6} \mathrm{~mol} / \mathrm{L}\right)$ and Losartan $\left(10^{-6} \mathrm{~mol} / \mathrm{L}\right)$, Ang II $\left(10^{-6} \mathrm{~mol} / \mathrm{L}\right)$ and the specific PlGF or VEGF neutralizing antibody $(10-20 \mu \mathrm{g} / \mathrm{mL})$ for 24 hours. Twenty microliters of MTT ( $15 \mathrm{mg} / \mathrm{mL}$, Sigma, USA) was added to each well and incubated for $4 \mathrm{~h}$ at $37^{\circ} \mathrm{C}$. The culture supernatant was discarded by aspiration and $150 \mu \mathrm{L}$ of dimethyl sulfoxide (DMSO, Sigma) was added for $10 \mathrm{~min}$. The light absorbance at $570 \mathrm{~nm}$ was detected using ELISA reader (Bio-Rad Model 680, USA).

\section{Statistical analysis}

The experimental data were expressed as means \pm SD. Group means were compared by One-way ANOVA using the statistical software program SPSS 10.0 for Windows (Chicago, IL, USA), and $P$ value $<0.05$ was considered significant in all cases.

\begin{abstract}
Authors' contributions
PP and HF conceived of the experiments, carried out all experiments and prepared the manuscript. $\mathrm{LZ}$ and $\mathrm{HH}$ conceived of the experiments and performed real-time RT-PCR. FL conceived of the experiments. WW performed cell culture. $Y G$ and $X L$ provided expert advice and interpretation of the study's results. All authors read and approved the final manuscript.
\end{abstract}

\section{Acknowledgements \\ This work was supported by grants from the National Natural Science Founda- tion of China, No. 30470437, No. 30870596 (Xiaojing Liu), No. 30700149(Yingq- iang Guo), No.30500222, No. 30871118 and No. 30971325 (Fengming Luo). We would like to acknowledge the assistance and critical advice provided by Dr. Jue Lin (University of California, San Francisco) and Dr. Rui Lin (Exelixis, Inc.) in the preparation of this manuscript.}

\author{
Author Details \\ ${ }^{1}$ Laboratory of Cardiovascular Diseases, National key Laboratory of Biotherapy \\ of Human Diseases, West China Hospital, Sichuan University, Chengdu 610041, \\ China, 2Department of Cardiology, West China Hospital, Sichuan University, \\ Chengdu 610041, China, ${ }^{3}$ Golden-card ward, West China Hospital, Sichuan \\ University, Chengdu 610041, China and ${ }^{4}$ Department of Thoracic \& \\ Cardiovascular surgery, West China Hospital, Sichuan University, Chengdu \\ 610041, China \\ Received: 2 November 2009 Accepted: 26 May 2010 \\ Published: 26 May 2010

\section{References} \\ 1. Ross R: Atherosclerosis--an inflammatory disease. N Engl J Med 1999, \\ 340(2):115-126. \\ 2. Libby P, Ridker PM, Maseri A: Inflammation and Atherosclerosis. \\ Circulation 2002, 105(9):1135-1143.
}

3. Kranzhofer R, Schmidt J, Pfeiffer CA, Hagl S, Libby P, Kubler W: Angiotensin induces inflammatory activation of human vascular smooth muscle cells. Arterioscler Thromb Vasc Biol 1999, 19(7):1623-1629.

4. Weiss D, Sorescu D, Taylor W: Angiotensin II and atherosclerosis. The American journal of cardiology 2001, 87(8 A):25-32.

5. Prasad A, Koh KK, Schenke WH, Mincemoyer R, Csako G, Fleischer TA Brown M, Selvaggi TA, Quyyumi AA: Role of angiotensin II type 1 receptor in the regulation of cellular adhesion molecules in atherosclerosis. Am Heart J 2001, 142(2):248-253.

6. Souza HP, Frediani D, Cobra AL, Moretti Al, Jurado MC, Fernandes TR, Cardounel AJ, Zweier JL, Tostes RC: Angiotensin II modulates CD40 expression in vascular smooth muscle cells. Clin Sci (Lond) 2009, 116(5):423-431.

7. Takata Y, Liu J, Yin F, Collins AR, Lyon CJ, Lee CH, Atkins AR, Downes M, Barish GD, Evans RM, Hsueh WA, Tangirala RK: PPARdelta-mediated antiinflammatory mechanisms inhibit angiotensin II-accelerated atherosclerosis. Proceedings of the National Academy of Sciences of the United States of America 2008, 105(11):4277-4282.

8. Billet S, Aguilar F, Baudry C, Clauser E: Role of angiotensin II AT1 receptor activation in cardiovascular diseases. Kidney Int 2008, 74(11):1379-1384.

9. Jones ES, Vinh A, McCarthy CA, Gaspari TA, Widdop RE: AT2 receptors: functional relevance in cardiovascular disease. Pharmacol Ther 2008, 120(3):292-316

10. Alexis JD, Wang N, Che W, Lerner-Marmarosh N, Sahni A, Korshunov VA, Zou Y, Ding B, Yan C, Berk BC, Abe J: Bcr kinase activation by angiotensin II inhibits peroxisome-proliferator-activated receptor gamma transcriptional activity in vascular smooth muscle cells. Circ Res 2009, 104(1):69-78.

11. Khurana R, Moons L, Shafi S, Luttun A, Collen D, Martin JF, Carmeliet P, Zachary IC: Placental growth factor promotes atherosclerotic intimal thickening and macrophage accumulation. Circulation 2005, 111(21):2828-2836.

12. Pilarczyk K, Sattler KJE, Galili O, Versari D, Olson ML, Meyer FB, Zhu XY, Lerman LO, Lerman A: Placenta growth factor expression in human atherosclerotic carotid plaques is related to plaque destabilization. Atherosclerosis 2008, 196(1):333-340.

13. Lenderink T, Heeschen C, Fichtlscherer S, Dimmeler S, Hamm CW, Zeiher AM, Simoons ML, Boersma E: Elevated Placental Growth Factor Levels Are Associated With Adverse Outcomes at Four-Year Follow-Up in Patients With Acute Coronary Syndromes. Journal of the American College of Cardiology 2006, 47(2):307-311

14. Errico M, Riccioni T, Iyer S, Pisano C, Acharya KR, Persico MG, De Falco S: Identification of Placenta Growth Factor Determinants for Binding and Activation of Flt-1 Receptor. J Biol Chem 2004, 279(42):43929-43939.

15. Yoo SA, Yoon HJ, Kim HS, Chae CB, De Falco S, Cho CS, Kim WU: Role of placenta growth factor and its receptor flt- 1 in rheumatoid inflammation: a link between angiogenesis and inflammation. Arthritis Rheum 2009, 60(2):345-354.

16. Carmeliet $P$, Moons L, Luttun A, Vincenti V, Compernolle V, De Mol M, Wu Y, Bono F, Devy L, Beck H, Scholz D, Acker T, DiPalma T, Dewerchin M, Noel A, Stalmans I, Barra A, Blacher S, Vandendriessche T, Ponten A, Eriksson U, Plate KH, Foidart JM, Schaper W, Charnock-Jones DS, Hicklin DJ, Herbert JM, Collen D, Persico MG: Synergism between vascular endothelial growth factor and placental growth factor contributes to angiogenesis and plasma extravasation in pathological conditions. Nat Med 2001, 7(5):575-583.

17. Heeschen C, Dimmeler S, Fichtlscherer S, Hamm CW, Berger J, Simoons ML, Zeiher AM: Prognostic value of placental growth factor in patients with acute chest pain. JAMA 2004, 291(4):435-441.

18. Torry RJ, Tomanek RJ, Zheng W, Miller SJ, Labarrere CA, Torry DS: Hypoxia increases placenta growth factor expression in human myocardium and cultured neonatal rat cardiomyocytes. J Heart Lung Transplant 2009, 28(2):183-190

19. Cramer M, Nagy I, Murphy BJ, Gassmann M, Hottiger MO, Georgiev O, Schaffner W: NF-kappaB contributes to transcription of placenta growth factor and interacts with metal responsive transcription factor1 in hypoxic human cells. Biol Chem 2005, 386(9):865-872.

20. Steinkamp-Fenske K, Bollinger L, Voller N, Xu H, Yao Y, Bauer R, Forstermann $\mathrm{U}$, Li H: Ursolic acid from the Chinese herb danshen (Salvia miltiorrhiza L.) upregulates eNOS and downregulates Nox4 expression in human endothelial cells. Atherosclerosis 2007, 195(1):e104-111. 
21. Xu H, Goettsch C, Xia N, Horke S, Morawietz H, Forstermann U, Li H: Differential roles of PKCalpha and PKCepsilon in controlling the gene expression of Nox4 in human endothelial cells. Free Radic Biol Med 2008, 44(8):1656-1667.

22. Cairrao E, Santos-Silva AJ, Alvarez E, Correia I, Verde I: Isolation and culture of human umbilical artery smooth muscle cells expressing functional calcium channels. In Vitro Cell Dev Biol Anim 2009, 45(3-4):175-184.

23. de Llano Martin JJ, Fuertes G, Torro I, Garcia Vicent C, Fayos JL, Lurbe E: Birth weight and characteristics of endothelial and smooth muscle cell cultures from human umbilical cord vessels. J Trans/ Med 2009, 7:30.

24. Zhao Q, Ishibashi M, Hiasa K, Tan C, Takeshita A, Egashira K: Essential role of vascular endothelial growth factor in angiotensin II-induced vascular inflammation and remodeling. Hypertension 2004, 44(3):264-270.

25. Kitayama H, Maeshima Y, Takazawa Y, Yamamoto $Y$, Wu Y, Ichinose $K$ Hirokoshi K, Sugiyama H, Yamasaki Y, Makino H: Regulation of angiogenic factors in angiotensin II infusion model in association with tubulointerstitial injuries. Am J Hypertens 2006, 19(7):718-727.

26. Wang Y, Yan T, Wang Q, Wang W, Xu J, Wu X, Ji H: PKC-dependent extracellular signal-regulated kinase $1 / 2$ pathway is involved in the inhibition of Ib on Angiotensinll-induced proliferation of vascular smooth muscle cells. Biochem Biophys Res Commun 2008, 375(1):151-155.

27. Ge X, Low B, Liang M, Fu J: Angiotensin II directly triggers endothelial exocytosis via protein kinase C-dependent protein kinase D2 activation. J Pharmacol Sci 2007, 105(2):168-176.

28. Jimenez E, de la Blanca Perez E, Urso L, Gonzalez I, Salas J, Montiel M: Angiotensin II induces MMP 2 activity via FAK/JNK pathway in human endothelial cells. Biochem Biophys Res Commun 2009, 380(4):769-774.

29. Liu L, Wen T, Zheng XY, Yang DG, Zhao SP, Xu DY, Lu GH: Remnant-like particles accelerate endothelial progenitor cells senescence and induce cellular dysfunction via an oxidative mechanism. Atherosclerosis 2009, 202(2):405-414

30. Wang QR, Wang F, Zhu WB, Lei J, Huang YH, Wang BH, Yan Q: GM-CSF accelerates proliferation of endothelial progenitor cells from murine bone marrow mononuclear cells in vitro. Cytokine 2009, 45(3):174-178.

31. Herr D, Rodewald M, Fraser HM, Hack G, Konrad R, Kreienberg R, Wulff C: Regulation of endothelial proliferation by the renin-angiotensin system in human umbilical vein endothelial cells. Reproduction 2008, 136(1):125-130.

32. He M, Han M, Zheng B, Shu YN, Wen JK: Angiotensin II stimulates KLF5 phosphorylation and its interaction with c-Jun leading to suppression of p21 expression in vascular smooth muscle cells. J Biochem 2009, 146(5):683-691.

33. Geng J, Zhao Z, Kang W, Wang W, Liu G, Sun Y, Zhang Y, Ge Z: Hypertrophic response to angiotensin II is mediated by protein kinase D-extracellular signal-regulated kinase 5 pathway in human aortic smooth muscle cells. Biochem Biophys Res Commun 2009, 388(3):517-522

34. Su KH, Tsai JY, Kou YR, Chiang AN, Hsiao SH, Wu YL, Hou HH, Pan CC, Shyue SK, Lee TS: Valsartan regulates the interaction of angiotensin II type 1 receptor and endothelial nitric oxide synthase via Src/PI3K/Akt signalling. Cardiovasc Res 2009, 82(3):468-475.

35. Iyer S, Acharya KR: Role of placenta growth factor in cardiovascular health. Trends Cardiovasc Med 2002, 12(3):128-134

36. Selvaraj SK, Giri RK, Perelman N, Johnson C, Malik P, Kalra VK: Mechanism of monocyte activation and expression of proinflammatory cytochemokines by placenta growth factor. Blood 2003, 102(4):1515-1524

37. Oura H, Bertoncini J, Velasco P, Brown LF, Carmeliet P, Detmar M: A critical role of placental growth factor in the induction of inflammation and edema formation. Blood 2003, 101(2):560-567.

38. Ling S, Dai A, Ma YH, Wilson E, Chatterjee K, Ives HE, Sudhir K: Matrixdependent gene expression of egr-1 and PDGF A regulate angiotensin II-induced proliferation in human vascular smooth muscle cells. Hypertension 1999, 34(5):1141-1146.

39. Kuma S, Oki E, Onohara T, Komori K, Maehara Y: Angiotensin Il-induced growth of vascular smooth muscle cells is associated with modulation of cell surface area and platelet-derived growth factor receptor expression. Clin Exp Pharmacol Physiol 2007, 34(3):153-160.

40. Rudijanto A: The role of vascular smooth muscle cells on the pathogenesis of atherosclerosis. Acta Med Indones 2007, 39(2):86-93.
41. Clarke M, Bennett M: The emerging role of vascular smooth muscle cell apoptosis in atherosclerosis and plaque stability. Am J Nephrol 2006 26(6):531-535.

42. Bellik L, Vinci MC, Filippi S, Ledda F, Parenti A: Intracellular pathways triggered by the selective FLT-1-agonist placental growth factor in vascular smooth muscle cells exposed to hypoxia. Br J Pharmacol 2005, 146(4):568-575

43. Araki-Taguchi M, Nomura S, Ino K, Sumigama S, Yamamoto E, Kotani-Ito T, Hayakawa H, Kajiyama H, Shibata K, Itakura A, Kikkawa F: Angiotensin II mimics the hypoxic effect on regulating trophoblast proliferation and differentiation in human placental explant cultures. Life Sci 2008, 82(12):59-67.

44. Mohammed KA, Nasreen N, Tepper RS, Antony VB: Cyclic stretch induces PIGF expression in bronchial airway epithelial cells via nitric oxide release. Am J Physiol Lung Cell Mol Physiol 2007, 292(2):L559-566.

doi: $10.1186 / 1471-2121-11-36$

Cite this article as: Pan et al., Angiotensin II upregulates the expression of placental growth factor in human vascular endothelial cells and smooth muscle cells BMC Cell Biology 2010, 11:36

\section{Submit your next manuscript to BioMed Central and take full advantage of:}

- Convenient online submission

- Thorough peer review

- No space constraints or color figure charges

- Immediate publication on acceptance

- Inclusion in PubMed, CAS, Scopus and Google Scholar

- Research which is freely available for redistribution
C) Biomed Central 